IBLAM LAW REVIEW

SEKOLAH TINGGI ILMU HUKUM IBLAM

Vol 1 No 1 2021, Hal 57-95

\title{
LEGAL REVIEW OF THE IMPLEMENTATION OF FEMALE DEVELOPMENT IN THE WOMEN'S CORRECTIONAL INSTITUTIONS CLASS IIA EAST JAKARTA
}

\author{
P.L. Tobing and Emsah Ulina \\ Departement of Law, IBLAM School of Law \\ Jalan Kramat Raya No.25, Jakarta Pusat
}

\begin{abstract}
Abstrack
The purpose of guiding prisoners in prison in Indonesia is so that prisoners can improve themselves so that the objectives of the correctional system can be achieved so that prisoners are nurtured and guided to become better people. A person becomes a prisoner not only because the factors that cause the crime that come from outside are material, but also because his mental and spiritual factors have been damaged as a result of mistakes and socialization that shape his personality. The formulation of the problems in this research are: 1 . How is the implementation of coaching for women assisted residents in LAPAS Perempuan? 2. What are the obstacles in the implementation of coaching for women assisted citizens at the Class IIA Women's Prison, East Jakarta? The research method that I use is a normative juridical method, which is to analyze the relationship between the prevailing laws and regulations with legal theories and the practice of implementing positive law concerning the issues discussed. The conclusion in this study is that the implementation of coaching for female prisoners at the Class IIA Women's Prison, East Jakarta, includes several procedures starting from the admission of prisoners, registration to the next stage of the implementation of the development of prisoners. The implementation stage itself consists of 4 (four) stages, namely the initial stage of teaching inmates to have religious and legal awareness, the advanced stage which gives directions to the inmates to always display their talents and skills so that while in prison, the prisoners have positive activities done. Furthermore, in the advanced stage, the two prisoners who have undergone half of their prison terms, which according to the Correctional Supervisory Team (TPP) are allowed to go outside the wall (assimilation), in the last stage are given provisions to become independent humans, live happily and participate actively in the community again. .

Some of the obstacles in the implementation of guidance for assisted citizens at LAPAS are conditions of overcapacity of LAPAS; Some of the prisoners do not have clear families; Lack of security personnel at LAPAS; Lack of attention to the fulfillment of institutional facilities at LAPAS; Lack of human resources such as teacher assistance and trainers.
\end{abstract}

Keywords: Guidance, Women Assisted Citizens, Correctional Institutions. 


\title{
TINJAUAN HUKUM PELAKSANAAN PEMBINAAN WARGA BINAAN WANITA DALAM SISTEM PEMASYARAKATAN DI LEMBAGA PEMASYARAKATAN PEREMPUAN KELAS IIA JAKARTA TIMUR
}

\author{
P.L. Tobing dan Emsah Ulina \\ Program Studi Sarjana Hukum, Sekolah Tinggi Ilmu Hukum IBLAM \\ Jalan Kramat Raya No. 25 Jakarta Pusat \\ Intisari
}

Tujuan pembinaan warga binaan pemasyarakatan di Indonesia adalah supaya narapidana dapat memperbaiki dirinya sehingga tujuan dari sistem pemasyarakatan dapat tercapai agar, narapidana dibina dan dibimbing menjadi orang yang lebih baik. Seseorang menjadi narapidana tidak hanya disebabkan faktor-faktor penyebab kejahatan yang datang dari luar bersifat material, tapi juga faktor mental spritualnya yang sudah rusak akibat dari kesalahan dan sosialisasi yang membentuk pribadinya. Rumusan masalah dalam penelitian ini adalah: 1.Bagaimana pelaksanaan pembinaan terhadap warga binaan wanita di LAPAS Perempuan? 2.Apa yang menjadi kendala pelaksanaan pembinaan warga binaan wanita di LAPAS Perempuan Kelas IIA Jakarta Timur?. Metode penelitian yang penulis gunakan adalah metode yuridis normatif yaitu menganalisis kaitan antara peraturan perundang-undangan yang berlaku dengan teori-teori hukum dan praktek pelaksanaan hukum positif yang menyangkut permasalahan yang dibahas. Kesimpulan dalam penelitian ini adalah bahwa Pelaksanaan pembinaan narapidana wanita yang ada di LAPAS Perempuan Kelas IIA Jakarta Timur memuat beberapa prosedur mulai dari penerimaan narapidana, pendaftaran hingga selanjutnya tahap pelaksanaan pembinaan narapidana. Di tahap pelaksanaan itu sendiri terdiri dari 4 (empat) tahap yakni tahap awal mengajarkan para narapidana untuk memiliki kesadaran agama dan hukum, tahap lanjutan yang memberi arahan kepada para narapidana untuk senantiasa menampilkan bakat dan ketrampilannya agar saat di dalam LAPAS, narapidana ada kegiatan positif yang dilakukan. Selanjutnya di tahap lanjutan yang kedua narapidana yang telah menjalani separuh masa pidananya yang menurut Tim Pengawas Pemasyarakatan (TPP) diperbolehkan untuk diluar tembok (Asimilasi), di tahap yang terakhir ini diberi bekal untuk menjadi manusia yang mandiri, hidup bahagia dan berpatisipasi aktif di masyakat kembali.

Beberapa kendala-kendala pelaksanaan pembinaan warga binaan di LAPAS adalah Kondisi over kapasitas LAPAS; Sebagian WBP tidak memiliki keluarga yang jelas; Masih kurangnya personil pengamanan pada LAPAS; Kurangnya perhatian terhadap pemenuhan fasilitas lembaga Pada LAPAS; Kurangnya SDM seperti tenaga bantuan Guru dan tenaga Pelatih.

Kata Kunci :Pembinaan, Warga Binaan Wanita, Lembaga Pemasyarakatan. 


\section{A. Pendahuluan}

Lembaga Pemasyarakatan (selanjutnya ditulis LAPAS) sebagai bagian dari sistem peradilan pidana bertujuan merealisasikan dari salah satu tujuan sistem peradilan pidana, yaitu meresosialisasi dan merehabilitasi pelanggar hukum. ${ }^{1}$ Tujuan pembinaan pelanggar hukum tidak semata-mata membalas dendam, tujuan sebenarnya dari pemidanaan di Indonesia adalah narapidana dapat memperbaiki dirinya sehingga tujuan dari sistem pemasyarakatan dapat tercapai yakni, narapidana atau warga binaan pemasyarakatan dianggap seseorang yang telah berbuat kekhilafan dan tersesat sehingga narapidana tersebut dibina dan dibimbing sehingga dapat menjadi orang yang lebih baik. ${ }^{2}$

Sistem pemasyarakatan adalah suatu tatanan mengenai arah dan batas serta cara pembinaan warga binaan pemasyarakatan berdasarkan Pancasila yang dilaksanakan secara terpadu antara Pembina, yang dibina, dan masyarakat untuk meningkatkan kualitas warga binaan pemasyarakatan agar menyadari kesalahan, memperbaiki diri, dan tidak mengulangi tindak pidana sehingga dapat diterima kembali oleh lingkungan masyarakat. ${ }^{3}$ Dalam LAPAS, warga binaan atau narapidana termasuk narapidana wanita yang melakukan tindak pidana menghadapi sejumlah permasalahan yang sangat

1 Atmasasmita, Romli (3). Dari Pemenjaraan ke Pembinaan Narapidana. Bandung: Alumni, 2001, hlm. 35

${ }^{2}$ Ibid., hlm. 37

3 Atmasasmita, Romli. (4). Dari Penjara Ke Pembinaan Narapidana. Bandung: Alumni. 2004, hlm. 71 berpengaruh terhadap psikologis mereka, sehingga diperlukan pembinaan secara khusus baginya.

Pembinaan di LAPAS menurut Undang-Undang Nomor 12 Tahun 1995 Tentang Pemasyarakatan (selanjutnya ditulis UU Pemasyarakatan), Pasal 12 ayat 1 dan 2 yakni: ${ }^{4}$

1. Dalam rangka pembinaan terhadap warga binaan atau narapidana di LAPAS dilakukan penggolongan atas dasar :
a. Umur;
b. Jenis kelamin;
c. Lama pidana yang dijatuhkan;
d. Jenis kejahatan; dan
e. Kriteria lainnya sesuai dengan kebutuhan atau perkembangan pembinaan.

2. Pembinaan Narapidana Wanita di Lapas dilaksanakan di LAPAS Wanita atau yang sekarang di sebut LAPAS Perempuan.

Khusus pembinaan narapidana wanita bukanlah suatu yang mudah,karena seseorang menjadi narapidana tidak hanya disebabkan faktor-faktor penyebab kejahatan yang datang dari luar bersifat material, tapi juga faktor mental spritualnya yang sudah rusak akibat dari kesalahan dan sosialisasi yang membentuk pribadinya. ${ }^{5}$

Berdasarkan pertimbangan di atas dapat dikemukakan bahwa,

${ }^{4}$ Budiningsih, Asri C. Pembelajaran Moral (Berpijak Pada Karakteristik dan Budayanya). Jakarta: Rineka Cipta. 2008, hlm. 103

5 Harsono,C.I. Sistem Baru Pembinaan Narapidana. Jakarta: Djambatan. Syofiyatul Lusiana, 2015, hlm. 92 
Lembaga Pemasyarakatan khusus wanita mempunyai tugas yang cukup berat dan upaya-upaya strategis, yakni dengan :

1.Mengembalikan $r$
narapidana wanita
wanita sebagai
sikap alamiah wanita adalah
lemah dan lembut, serta
narapidana wanita tersebut
mendapatkan pembekalan
hidup bermasyarakat, tentunya
yang banyak faktor yang
diperoleh selama narapidana
wanita tersebut berada dalam
LAPAS diantaranya dibekali
keterampilan dan keahlian
agar nantinya dapat
dipergunakan rantuk
memenuhi kebutuhan hidupnya di dalam masyarakat

2.Menyembuhkan mental dan kejiwaan yang sudah parah, akibat dari proses sosialisasi di lingkungan sebelumnya. Membentuk kepribadian yang lebih baik agar nantinya dapat bersosialisasi dengan baik dalam kehidupan bermasyarakat.

Adapun rumusan masalah yang akan dibahas dalam penelitan ini adalah :

1. Bagaimana pelaksanaan pembinaan terhadap warga binaan wanita di LAPAS Perempuan?

2. Apa yang menjadi kendala pelaksanaan pembinaan

${ }^{6}$ Peranan Lembaga Pemasyarakatan Dalam Pembinaan Kesadaran Moral Warga Binaan Di Lapas Wanita Kelas IIA Bandung Universitas Pendidikan Indonesia repository.upi.edu perpustakaan.upi.edu/diakses-21-Agustus2019 warga binaan wanita di LAPAS Perempuan Kelas IIA Jakarta Timur?

Tujuan penulis melaksanakan penelitian ini adalah :

1. Untuk menjelaskan dan menganalisis tentang pelaksanaan pembinaan terhadap warga binaan wanita di LAPAS Perempuan ;

2. Untuk mengetahui dan memahami tentang upaya mengatasi kendala dalam pelaksanaan pembinaan terhadap warga binaan wanita di LAPAS Perempuan Kelas IIA Jakarta Timur.

\section{B. Metode Penelitian}

Metode penelitian berperan penting untuk mendapatkan data yang akurat dan terpercaya. Metode penelitian ini juga digunakan sebagai alat atau cara untuk pedoman dalam melakukan penelitian. Spesifikasi penelitian yang di gunakan dengan berjudul : “ Tinjauan Hukum Tentang Pelaksanaan Pembinaan Terhadap Warga Binaan Wanita Dalam Sistem Pemasyarakatan Di Lembaga Pemasyarakatan Perempuan Kelas IIA Jakarta Timur", adalah yuridis normatif yaitu menganalisis kaitan antara peraturan perundang-undangan yang berlaku dengan teori-teori hukum dan praktek pelaksanaan hukum positif yang menyangkut permasalahan yang dibahas. Penelitian ini akan menganalisis masalah hukum, fakta, dan gejala hukum lainnya yang berkaitan dengan pendekatan hukum, kemudian di peroleh gambaran yang menyeluruh mengenai masalah yang akan di teliti. Penelitian yang 
berbentuk deskriftif analisis ini hanya akan menggambarkan keadaan objek atau persoalan dan tidak dimaksudkan mengambil atau menarik kesimpulan yang berlaku umum mengenai Pelaksanaan Pembinaan Terhadap Warga Binaan Wanita Dalam Sistem Pemasyarakatan. ${ }^{7}$

Metode pendekatan yang dilakukan dalam penelitian hukum ini adalah dengan menggunakan metode pendekatan yuridis normatif. Penelitian hukum normatif merupakan penelitian yang mengutamakan data kepustakaan yaitu penelitian terhadap data sekunder. Data sekunder tersebut dapat berupa bahan hukum primer,sekunder maupun tersier. ${ }^{8}$ Penelitian ini meliputi penelitian mengenai ketentuan hukum positif yang berlaku di Indonesia yang berkaitan dengan Pelaksanaan Pembinaan Terhadap Warga Binaan Wanita Dalam Sistem Pemasyarakatan.

Tahap penelitian yang dilakukan penulis adalah penelitian kepustakaan sebagai berikut :

Penelitian Kepustakaan sebuah teknik yang mengumpulkan data sekunder dengan cara mempelajari dan menganalisis bahan-bahan hukum dalam penelitian. Data yang teliti dapat berwujud data yang di peroleh melalui bahan-bahan kepustakaan dan/atau secara langsung dari masyarakat. Penelitian Kepustakaan ini terdiri dari:

7 Soerjono, Soekanto, Pengantar Penelitian Hukum, UI Press, Jakarta, 2010, hlm. 81

8 Ronny Hanitijo, Metodologi Penelitian Hukum, Jakarta : Ghalia Indonesia, 1990, hlm.24 a. Bahan Hukum Primer

Bahan-bahan hukum yang digunakan dalam penelitian dengan kekuatan yang mengikat meliputi norma dan kaidah dasar seperti, peraturan perundang-undangan catatancatatan resmi atau risalah dalam pembuatan perundang undangan, dan putusan hakim, dalam penelitian dan penulisan skripsi ini, meliputi : ${ }^{9}$ Undang-Undang Nomor 12 Tahun 1995 tentang Pemasyarakatan dan Peraturanperaturan lainnya yang berkaitan dengan judul skripsi.

b. Bahan Hukum Sekunder

Bahan-bahan yang memberikan penjelasan mengenai bahan hukum primer dan implementasinya, seperti hasil-hasil penelitian, hasil karya dari kalangan hukum, makalah-makalah seminar, dan lain-lain. Dalam penelitian dan penulisan skripsi ini meliputi bahan-bahan bacaan yang ada hubungannya dengan masalah peran, tugas, dan kewenangan jurusita sebagai objek yang teliti yaitu literatur dan karya ilmiah yang berkaitan dengan masalah yang akan di teliti.

c. Bahan Hukum Tersier

Bahan hukum yang memberikan penjelasan lebih lanjut dari bahan hukum primer dan sekunder yaitu, kamus, baik kamus terjemahan maupun kamus hukum, majalah dan internet (virtual research). ${ }^{10}$

Data yang di peroleh dari hasil penelitian yang di dapat secara langsung pada objek penelitian, yaitu

9 Mahmud Marzuki, Penelitian Hukum, Kencana, Jakarta, 2010, hlm. 141

10 Soekanto Soerjono dan Sri Mamudji, Penelitian Hukum Normatif Suatu Tinjauan Singkat, PT RajaGrafindo Persada, 1995, hlm. 62 
dengan cara studi Kepustakaan Studi Kepustakaan di lakukan dengan penelitian yang sifatnya litelatur untuk mencari, menemukan dan menggunakan bahanbahan mengenai konsepsi-konsepsi, teori-teori, atau pun pendapat-pendapat ahli yang berkaitan dengan permasalahan yang menjadi objek penelitian dan penulisan skripsi. ${ }^{11}$ Sesuai dengan permasalahan yang menjadi pokok bahasan penelitian penulis, maka penelitian yang akan di gunakan adalah penelitian yuridis normatif yaitu data sekunder yang di peroleh secara kualitatif untuk mencapai kejelasan masalah yang di bahas untuk dirumuskan dan disimpulkan. ${ }^{12}$

\section{Hasil Penelitian Dan Pembahasan \\ Pelaksanaan Pembinaan Terhadap Warga Binaan Wanita Di Lembaga Pemasyarakatan Perempuan}

Menurut UU Pemasyarakatan, pengaturan mengenai lokasi warga binaan pemasyarakatan jenis kelamin wanita, ditempatkan pada ruang terpisah. Pemisahan tersebut sudah tentu mempunyai tujuan yang mendasar. Misalnya, terjadi hubungan gelap antara napi perempuan dan laki-laki yang sudah tentu menjadi larangan di dalam lapas atau pun hal-hal lain yang tidak diinginkan.Dalam kehidupan seharihari, wanita yang menjadi warga binaan pemasyarakatan LAPAS, tak jauh berbeda dengan LAPASLAPAS yang ada di Indonesia.

\footnotetext{
11 Ibid.

${ }^{12}$ Bambang Mudjianto, Petunjuk

Praktis Metode Penelitian Kualitatif, Tiarana Lokus, yogyakarta, 2014, hlm.3.
}

Keseragaman tersebut disebabkan oleh aturan-aturan yang ditetapkan oleh pemerintah pusat sebagai landasan untuk dipatuhi warga binaan pemasyarakatan. Pada keseharian- nya, warga binaan pemasyarakatan selanjutnya ditulis (WBP), difokuskan pada pembinaan itu sendiri. Pembinaan ini diharapkan menimbulkan efek jera dan mereka tidak mengulangi lagi perbuatan melanggar hukum tersebut, seperti misalnya mereka rajin beribadah. ${ }^{13}$

Menurut petugas LAPAS, keberadaan mereka yang berada di tempat ibadah tersebut, dikarenakan kesadaran yang timbul pada warga binaan wanita itu sendiri. Namun, mereka yang tidak diberikan tugas atapun tidak pergi ke tempat ibadah, hanya kembali ke tempat atau bloknya dan membersihkan bloknya. Warga binaan wanita yang datang ke masjid, rajin mengikuti acara-acara pengajian, dan yang ke Gereja biasanya mengikuti latihan paduan suara dalam rangka mengisi kegiatan hari raya gereja ataupun kegiatan ibadah. Di dalam UU Pemasyarakatan, ternyata masalah narapidana wanita tidak disebutkan pengaturannya.

Karena yang disebutkan hanya narapidana, tidak dibedakan antara narapidana laki-laki maupun narapidana wanita, ini berarti telah terjadi kekosongan norma, sehingga ke depan hal ini perlu mendapat pengaturan norma antara narapidana laki-laki dan narapidana wanita tidak bisa diperlakukan sama, mengingat perbedaan fisik maupun psikologis antara laki-laki dan wanita.

13 Soerjono, Soekanto, Pengantar Penelitian Hukum, Op. Cit, hlm. 82 
Pelaksanaan pembinaan narapidana setelah adanya beberapa tahap terdapat tahap sesuai masa pidana yang dijalani (1) Tahap Awal $\pm 1 / 3$ Masa Pidana. Merupakan Admisi dan Orientasi yaitu masa pengamatan, pengenalan, dan penelitian lingkungan paling lama 1 bulan. Pembinaan di dalam Lapas, mencakup kegiatan penjelasan dan pemahaman tentang hak, kewajiban dan peraturan tata tertib yang berlaku, proses-proses pelaksanaan pembinaan atau perawatan, serta perkenalan dengan para petugas Pembina maupun sesama narapidana yang berguna bagi pelaksanaan kegiatan pembinaan atau perawatan selanjutnya (2) Tahap Lanjutan $\pm 1 / 2$ $2 / 3$ Masa Pidana (Asimilasi) merupakan suatu proses pembinaan terhadap narapidana yang dilaksanakan dengan membaurkan narapidana di dalam kehidupan masyarakat (berada di luar tembok).

Salah satu syarat untuk mengikuti kegiatan asimilasi ini adalah apabila narapidana telah menjalani $1 / 2$ dari masa pidananya, setelah dikurangi masa tahanan dan remisi dihitung sejak putusan pengadilan memperoleh kekuatan hukum tetap (3) Tahap Akhir $\pm 2 / 3$ Masa Pidana - bebas ( Masa Integrasi ) merupakan jika proses pembinaan telah menjalani $2 / 3$ dari masa pidananya menurut tim pengawas pemasyarakatan (TPP) narapidana yang bersangkutan dinilai relatif siap untuk diterjunkan lagi di masyarakatBerdasarkan ketentuan UU Pemasyarakatan pasal 1 dan 2, maka dibuatlah LAPAS khusus untuk Perempuan. Tujuan didirikannya LAPAS perempuan tersebut adalah untuk memisahkan antara narapidana pria dengan narapidana wanita dengan alasan faktor keamanan dan psikologis.

Adapun cara pambinaan di LAPAS narapidana wanita pada dasarnya tidak jauh berbeda dengan LAPAS pada umumnya. Hanya saja ada sedikit kekhususan dimana di LAPAS narapidana wanita diberikan pembinaan keterampilan seperti menjahit, menyulam, kristik dan memasak yang identik dengan pekerjaan sehari-hari kaum wanita. Selain itu LAPAS Perempuan juga memberikan cuti haid bagi narapidananya yang mengalami menstruasi. Dalam hal melakukan pekerjaan, narapidana wanita diberikan pekerjaan yang relatif lebih ringan jika dibandingkan dengan narapidana laki-laki. Hal ini mengingat fisik wanita biasanya lebih lemah jika dibandingkan dengan narapidana laki-laki. Selain diberikan beberapa keterampilan seperti tersebut diatas, LAPAS Perempuan juga memberikan keterampilan lain berupa pelajaran PKK. Hal ini dimaksudkan supaya bila kelak mereka keluar dari Lembaga Pemasyarakatan, mereka sudah mempunyai keterampilan sendiri sehingga dapat menjadi manusia yang mandiri dan berguna bagi diri sendiri, keluarga dan masyarakat pada umumnya serta dapat bersosialisasi dengan masyarakat disekitarnya. ${ }^{14}$

Sedangkan untuk narapidana wanita yang sedang hamil atau menyusui diberikan perlakuan khusus. Hal ini diatur dalam Peraturan Pemerintah Nomor 32

${ }^{14}$ Pengamatan Penulis Sebagai ASN di lingkungan LAPAS Perempuan Kelas IIA Jakarta Timur 
Tahun 1999 tentang Syarat dan Tata Cara Pelaksanaan Hak Warga Binaan Pemasyarakatan pasal 20 ayat $(3,4$ dan 5), Narapidana dan anak didik pemasyarakatan yang sakit, hamil atau menyusui, berhak mendapatkan makanan tambahan sesuai dengan petunjuk dokter.Di lapangan menunjukkan bahwa praktek-praktek pemidanaan selama ini, satu sisi harus dengan pendekatan keamanan dan sisi lainnya harus melakukan pembinaan (pendidikan) dengan koridor hak asasi manusia. Harus ada keseimbangan antara kedua hal tersebut, sehingga tujuan pemidanaan di Indonesia yang telah dirintis pendahulu kita mempunyai tujuan yang lebih terukur dan pasti.

Penghuni yang berada di LAPAS Perempuan Kelas IIA Jakarta Timur, yakni jumlah tahanan: 0 orang karena di LAPAS Perempuan Kelas IIA Jakarta Timur tidak Ada tahanan, jumlah Narapidana: 393 Orang (Juni 2019). Pembinaan kesadaran beragama, berupa pesantren kilat, sholat bersama, ibadah rohani Pukul 09.0012.00 dan ceramah diikuti oleh 150 orang Narapidana. Anggaran kegiatatan keagamaan ini adalah Rp. 17,8 Juta/tahun. Pembinaan kesadaran berbangsa dan bernegara, berupa upacara bendera, hari besar nasional, hari Pemasyarakatan, hari Dharmakaryadhika, penyuluhan Pancasila/Bhineka Tunggal Ika, dilaksanakan pada pukul 10.0011.00, 09.00-10.00, 11.00-12.00.

Sedangkan acara penyuluhan Kesehatan diikuti oleh 50 Narapidana dengan anggaran penyuluhan adalah Rp. 10,5 juta/tahun. Pembinaan kemampuan intelektual (kecerdasan), berupa pemberian pengetahuan agama secara garis besar yang dilaksanakan pada pukul 15.30-17.30 dan kegiatan olah raga diikuti oleh 34 orang Narapidana dengan anggaran $\mathrm{Rp}$. 11,6 juta/tahun. Pembinaan mengintegrasikan diri dengan masyarakat, berupa kegiatan pramuka, kerja asimilasi, Kesenian dengan anggaran Rp. 22,3 juta/tahun. ${ }^{15}$

\section{Kendala yang Dihadapi Dalam Pelaksanaan Sistem Pembinaan Warga Binaan Wanita Di Lembaga Pemasyarakatan Perempuan Kelas IIA Jakarta Timur}

Perlu dipahami bahwa dalam suatu konsep pembinaan terhadap narapidana wanita di LAPAS yang menjadi bagian dari tujuan petugas yang erat kaitannya dengan keberhasilan pengembalian narapidana wanita kemasyarakat, dengan demikian bentuk pola pembinaan yang diberikan terhadap narapidana wanita sangat besar pengaruhnya terhadap keberhasilan maupun kegagalan pengembalian narapidana kemasyarakat. ${ }^{16}$

Untuk mencapai keberhasilan pembinaan tidak jarang ditemui beberapa hambatan atau kendala dalam memberikan pembinaan narapidana wanita di LAPAS, khususnya di LAPAS Perempuan Kelas IIA Jakarta Timur, hambatan persoalan yang ditemukan di LAPAS Perempuan Kelas IIA Jakarta Timur

${ }^{15}$ Pengamatan Penulis Sebagai ASN di lingkungan LAPAS Perempuan Kelas IIA Jakarta Timur

16 Atmasasmita, Romli. (4). Dari Penjara Ke Pembinaan Narapidana, Op. Cit., hlm,. 93 
berarti pula hambatan yang menyertai narapidana nantinya setelah narapidana mendapatkan kebebasannya.

Sebenarnya selama ini tidak ada masalah yang cukup serius dalam pembinaan narapidana hanya kapasitas yang overload yang ada di LAPAS Perempuan Kelas IIA Jakarta Timur. Namun hambatanhambatan tersebut tidak membuat petugas LAPAS Perempuan Kelas IIA Jakarta Timur menyerah dan putus asa dalam menyelenggarakan kegiatan pembinaan narapidana. Karena kegiatan pembinaan tetap dilaksanakan semaksimal mungkin untuk mencapai tujuan pembinaan dan agar dapat berguna bagi narapidana serta dapat kembali ke dalam kehidupan masyarakat.

Selain hal itu berdasarkan dampak model pembinaan nya (a) Diadakannya pembinaan beragama bagi para narapidana yang tidak pandai sholat, menjadi pandai dan paham tentang sholat yang baik dan benar (b) Bagi narapidana yang tidak pandai mengaji, ${ }^{17}$ setelah keluar dari LAPAS Perempuan Kelas IIA Jakarta Timur menjadi pandai mengaji bahkan dapat mengajar mengaji untuk orang lain setelah yang bersangkutan keluar dari LAPAS Perempuan Kelas IIA Jakarta Timur

Upaya yang dilakukan untuk upaya-upaya yang dilakukan oleh LAPAS Perempuan Kelas IIA Jakarta Timur dalam Mengatasi Over Capacity (a) Mengajukan permohonan untuk merenovasi atau

${ }^{17}$ Pengamatan Penulis Sebagai ASN di lingkungan LAPAS Perempuan Kelas IIA Jakarta Timur memperbaharui bangunan yang sudah ada (b) Mengurangi atau membatasi narapidana ke LAPAS Perempuan Kelas IIA Jakarta Timur. Hal-hal yang dapat dilakukan melalui program antara lain yaitu (1) Mengintensifkan bentuk Tahanan Rumah dan Tahanan Kota, kegiatan ini dapat dilakukan dalam setiap tingkat penahanan yaitu pada tingkat penyidikan, tingkat penuntutan dan tingkat pemeriksaan oleh Pengadilan. Bentuk penahanan rumah dan penahanan Kota ini secara tegas diatur dalam pasal 22 ayat (1) KUHAP. (2) Mengintensifkan bentuk penjatuhan Hukuman Pidana Bersyarat. (3) Mengintensifkan Pemberian Pidana Denda sebagaimana yang diatur pasal 10 huruf a angka 4c KUHP. (4) Mengoptimalkan pemanfaatan hasil Penelitian Kemasyarakatan yang dilakukan oleh Balai Bapas (5) Menyurati/menghubungi pihak kejaksaan agar segera mengirim putusan/vonis $^{18}$ ke LAPAS Perempuan Kelas IIA Jakarta Timur. Proses pemasyarakatan narapidana akan berjalan efektif apabila narapidana diberikan kesempatan seluas-luasnya untuk berinteraksi dan berbaur dengan masyarakat melalui Proses Asimilasi dan Integrasi.

Pelaksanaan pembinaan terhadap warga binaan agar dapat dikembangkan potensinya kearah yang positif sebagai sarana merubah seseorang menjadi manusia produktif, untuk menjadi lebih baik dari sebelum menjalani pemidanaan. Pemberian kegiatan untuk pengembangan keterampilan bagi warga binaan, melalui petugas 
lembaga pemasyarakatan diharapkan agar kelak kembali ketengah-tengah masyarakat tidak lagi mengulangi perbuatan-perbuatan yang bertentangan dengan hukum yang berlaku. Demikian pula agar pembinaan ini dapat memberikan motivasi bagi hasil perubahan diri dalam enyongsong masa depan yang lebih baik. Akan tetapi dalam mewujudkan tujuan yang mulia ini, belum dapat sepenuhnya terimplementasi secara berkesinambungan karena terdapat beberapa kendala yang dialami. ${ }^{19}$ Berdasarkan hasil wawancara dengan petugas LAPAS Perempuan Kelas IIA Jakarta Timur.

Rendahnya minat dan kepedulian dari lembaga atau perusahaan untuk berperan serta dalam memberikan binaan kepada warga binaan di LAPAS. Hal ini terjadi karena tugas-tugas di LAPAS khususnya LAPAS Perempuan Kelas IIA Jakarta Timur tidak dapat memberikan kontribusi secara timbal balik, dan tidak dapat menumbuhkan rasa kebanggaan. Hal ini disebabkan, masalah dukungan pendanaan dalam pembinaan terhadap kegiatankegiatan yang bersifat keterampilan yang dapat digunakan untuk menciptakan pekerjaan sendiri atau dapat bekerja pada pihak lain sesuai keterampilan yang dimiliki. ${ }^{20}$

Sistem Pemasyarakatan sebagai wadah untuk melakukan pembinaan terhadap warga binaan, sebagai paradigma fungsi Lembaga Pemasyarakatan yang tadinya

19 Diah Gustiani. dkk.Hukum Penitensia dan Sistem Pemasyarakatan di Indonesia, Op.Cit., hlm. 104

${ }^{20}$ Ibid., hlm. 105 sebagai tempat pembalasan menjadi tempat untuk melakukan pembinaan. Kendala-kendala yang dihadapi oleh petugas pemasyarakatan dalam upaya memberikan pembinaan bagi warga binaan disebabkan karena : Kondisi over kapasitas penghuni LAPAS sehingga pembinaan tidak berjalan secara optimal. Dan sebagian warga binaan tidak memiliki keluarga yang jelas, sehingga tidak ada pihak dari keluarga yang ikut memberikan support dengan melakukan kunjungan ke LAPAS. Hal ini juga berdampak tidak adanya jaminan keluarga yang harus diketahui oleh Lurah di Wilayah tempat tinggal Narapidana.

\section{Kesimpulan}

Pelaksanaan pembinaan narapidana wanita yang ada di LAPAS Perempuan Kelas IIA Jakarta Timur memuat beberapa prosedur mulai dari penerimaan narapidana, pendaftaran hingga selanjutnya tahap pelaksanaan pembinaan narapidana. Di tahap pelaksanaan itu sendiri terdiri dari 4 (empat) tahap yakni tahap awal mengajarkan para narapidana untuk memilikin keasadaran agama dan hukum, tahap lanjutan yang memberi arahan kepada para napi untuk senantiasa menampilkan bakat dan ketrampilannya agar saat di dalam LAPAS, narapidana ada kegiatan positif yang dilakukan. Selanjutnya di tahap lanjutan yang kedua narapidana yang telah menjalani separuh masa tahanannya yang menurut TPP (Tim Pengawas Pemasyarakatan) diperbolehkan untuk diluar tembok, di tahap yang terakhir ini tahap dimana napi yang 
hampir keluar dan selesai menjalani masa tahanannya diberi bekal untuk menjadi manusia yang mandiri, hidup bahagia dan berpatisipasi aktif di masyakat kembali. Hal ini didukung dengan adanya kerjasama antara Kementerian Hukum dan Ham dengan Menteri Ketenagakerjaan yang tertuang dalam perjanjian tentang Program Pelatihan Kerja Bagi Warga Binaan Pemasyarakatan serta Rehabilitasi Sosial dan Reintegrasi Sosial Bekas Warga Binaan Pemasyarakatan bertujuan mempersiapkan kemandirian Warga Binaan Pemasyarakatan untuk kembali ke masyarakat.

Kendala pelaksanaan pembinaan warga binaan wanita di LAPAS Perempuan Kelas IIA Jakarta Timur, hampir sama dengan LAPASLAPAS di Indonesia yaitu ;

Kondisi over kapasitas penghuni LAPAS sehingga pembinaan tidak berjalan secara optimal ;

Sebagian warga binaan tidak memiliki keluarga yang jelas, sehingga tidak ada pihak dari keluarga yang ikut memberikan support dengan melakukan kunjungan ke LAPAS. Hal ini juga berdampak tidak adanya jaminan keluarga yang harus diketahui oleh Lurah di Wilayah tempat tinggal Narapidana ;

$$
\text { Masih kurangnya personil }
$$

pengamanan pada LAPAS

Perempuan Kelas IIA Jakarta Timur;

Kurangnya perhatian terhadap pemenuhan fasilitas lembaga pada LAPAS Perempuan Kelas IIA Jakarta Timur ;

Kurangnya Sumber Daya Manusia, seperti tenaga bantuan guru dan pelatih.
Kegiatan-kegiatan yang diberikan dalam rangka pembinaan kepada warga binaan wanita di LAPAS Perempuan, seyogyanya difokuskan kepada kegiatan yang bermanfaat yang dapat berguna bagi narapidana kelak dengan cara menggali potensi dan kompetensi yang dimiliki oleh masing-masing warga binaan, meskipun jenis kegiatan yang diberikan pasti akan beragam. Hal ini memang diperlukan inovasi dari para petugas LAPAS dan kebijakan dari Kepala LAPAS yang disesuaikan dengan keterbatasan sarana yang ada dalam LAPAS.

\section{E. Daftar Pustaka}

\section{Buku}

Atmasasmita, Romli (1), Strategi Pembinaan Pelanggaran Hukum Dalam Konteks Penegakan Hukum Di Indonesia. Bandung: Alumni. 2003

Atmasasmita, Romli (2). Strategi Pembinaan Pelanggaran Hukum dalam Konteks Penegakan Hukum di Indonesia. Bandung: Alumni. 2002

Atmasasmita, Romli (3). Dari Pemenjaraan ke Pembinaan Narapidana. Bandung: Alumni, 2001

Atmasasmita, Romli. (4). Dari Penjara Ke Pembinaan Narapidana. Bandung: Alumni. 2004

Bambang Mudjianto, Petunjuk Praktis Metode Penelitian Kualitatif, Tiarana Lokus, yogyakarta, 2014

Budiningsih, Asri C. Pembelajaran Moral (Berpijak Pada Karakteristik dan Budayanya). Jakarta: Rineka Cipta. 2008 
Daradjat, Zakiah. Membina NilaiNilai Moral di Indonesia. Jakarta: Bulan Bintang. 1999

Diah Gustiani. dkk.Hukum Penitensia dan Sistem Pemasyarakatan di Indonesia.Bandar Lampung. 2013

Harsono,C.I. Sistem Baru Pembinaan Narapidana. Jakarta: Djambatan. 2002

Syofiyatul Lusiana, Peranan Lembaga Pemasyarakatan Dalam Pembinaan Kesadaran Moral Warga Binaan Di Lapas Wanita Kelas IIA Bandung Universitas Pendidikan Indonesia | repository.upi.edu | perpustakaan.upi.edu-2015

Mahmud Marzuki, Penelitian Hukum, Kencana, Jakarta, 2010

Poespoprojo. Filsafat Moral. Bandung: Pustaka Grafika. 1999

Priyatno, Dwidja. Sistem Pelaksanaan Pidana Penjara Di
Indonesia. Bandung: Refika Aditama. 2006

Ronny Hanitijo, Metodologi Penelitian Hukum, Jakarta : Ghalia Indonesia, 1990

Samosir, Djisman, Sekelumit Tentang Penologi Dan Pemasyarakatan. Bandung: Nuansa Aulia, 2012

Soerjono, Soekanto, Pengantar Penelitian Hukum, UI Press, Jakarta, 2010

Soekanto Soerjono dan Sri Mamudji, Penelitian Hukum Normatif Suatu Tinjauan Singkat, PT RajaGrafindo Persada, 1995

Tolib Setiady, Pokok-Pokok Hukum Penitensier Indonesia, Alfabeta, Bandung, 2010.

Peraturan Perundang-undangan : Undang-Undang Nomor 12 Tahun 1995 Tentang Lembaga Pemasyarakatan 